\title{
Assessment of importance of ecosystem services of Henan province
}

\author{
Qing-Min ZHANG \& Cai-Feng YUAN*\&Jing WANG \& Jun-Cang XIAO \& Xin \\ LU\& Xiao-Guo ZHANG \\ Henan Academy of Environment Protection ,Zhengzhou, China
}

KEYWORD: Ecosystem services; Assessment of importance; Henan province

\begin{abstract}
The study selected the importance of water conservation, the importance of soil and water conservation and the importance of biodiversity protection to comprehensively assess the importance of ecosystem service function and its regional variation of Henan province. Results showed that the extremely important and important area of ecosystem service function in Henan province is mainly located in Taihang mountain, Funiu mountain, and Dabie mountain.
\end{abstract}

\section{INSTRUCTION}

Ecosystem is the basis for human survival and development. Ecosystem plays a wide variety of functions to provide a variety of services through its own environment, material and energy exchange with the outside world. Ecosystem services are the current hot problems of ecology. The assessment of the importance of ecosystem services is assessing the integrated features and spatial distribution characteristics of ecosystem services based on the services or the value of typical ecosystem. The assessment results are calculated by applying ecology model to simulate the typical spatial differentiation of eco-system services, then overlaying different maps of assessment of the importance of ecosystem services. In recent years, there are a lot of related research in this field. XiangB, et al selected biodiversity conservation, water conservation and soil conservation to assess the importance of ecosystem services of Chengdu-Chongqing economic zone. Niu $\mathrm{S} W$, et al divided ecological protection zones by assessing ecosystems services based on partition, and accounting for ecosystem service value. To sum up, the main research methods are factor superimposed method and InVEST model method.

The assessment of importance of ecosystem services is the basis for the delineation of ecological protection red line. The research taking Henan province as an example, selected water conservation, soil conservation and biodiversity maintenance to assess the importance of ecosystem services to provide technical support for the delineation of ecological protection red line of Henan province.

\section{Regional Overview}

Henan province located in central China, locatedat $31^{\circ} 23 \quad \mathrm{~N} \sim 36^{\circ} 22 \mathrm{~N}, 110^{\circ} 21 \mathrm{E} \sim 116^{\circ} 39$. The area ratio of plain, mountain and hill are respectively55.69\%, 26.59\% and $17.72 \%$. The basic terrain of Henan province mainly includes Yudong plain, Nanyang basin, Yubei mountain, Yuxi mountain and Yunan mountain. Henan province belongs to the continental monsoon climate. The annual precipitation decreasing from South to North is between $1000 \sim 1200 \mathrm{~mm}$.

\section{Methods}

\subsection{Assessment methods of importance of water conservation function}

Water conservation refers to the ecosystem regulates water circulation through its unique structure to ease surface runoff, recharge groundwater, and improve water quality.

The study used water conservation as the indicator of water conservation function. The water conservation was assessed by water decomposition method based on precipitation and evapotranspiration. The method employed a highly generalized land cover factor to ensure the reliability of the results. 
$W Y=P-W T$

$$
E T=\frac{P\left(1+\omega \frac{\text { PET }}{P}\right)}{1+\omega \frac{\text { PET }}{P}+\frac{P}{P E T}}
$$

WY-Water conservation;

$P$-Average annual precipitation;

ET-Evapotranspiration;

$P E T$ - The average potential evaporation;

$\omega$-The underlying surface influence coefficients based on the value of land use types.

Table1 The parameter reference value of assessment of importance of water conservation function

\begin{tabular}{cc}
\hline Land use types & $\boldsymbol{\omega}$ \\
\hline Arable land & 0.5 \\
High covered forest land & 2 \\
Low covered forest land & 1 \\
Shrub & 1 \\
Grassland & 0.5 \\
Artificial land & 0.1 \\
Other land use & 0.1 \\
\hline
\end{tabular}

The assessment was divided into 4 levels including unimportant, generally important, important and extremely important by GIS.

\subsection{Assessment methods of importance of soil and water conservation function}

Soil and water conservation is one of the important services provided by the ecosystem, referring to the ecosystem reduces the soil erosion caused by water erosion through its structure and processes. Soil and water conservation functions is mainly related to climate, soil, topography and vegetation.

The study used soil conservation which is the difference of the potential and the actual soil erosion amount as the indicator of soil and water conservation function. The method employed USLE to assess soil and water conservation.

$$
A_{C}=A_{p}-A_{r}=R \times K \times L \times S \times(1-C)
$$

Ac-Soil conservation;

$A p$-Potential of soil erosion;

$A r-$ Actual amount of soil erosion;

$R$-Precipitation factors;

$K$-Soil erosion factors;

$L 、 S$-Topographic factors;

$C$-Vegetation cover factors;

The assessment was divided into 4 levels including unimportant, generally important, important and extremely important by GIS.

\subsection{Assessment methods of importance of biodiversity conservation function}

Biodiversity conservation function referring to the role the ecosystem playing in maintaining the diversity of genes, species, ecosystems is one of the most important functions of ecosystem. 
Table2 The assessment of importance of biodiversity conservation function table

\begin{tabular}{ccc}
$\begin{array}{c}\text { The ratio of ecosystems or species } \\
\text { account for the province's total number } \\
\text { of species }\end{array}$ & $\begin{array}{c}\text { National and } \\
\text { provincial protected } \\
\text { species }\end{array}$ & Importance \\
\hline$>30 \%$ & National level one & Extremely important \\
$15-30 \%$ & National level two & Important \\
$5-15 \%$ & $\begin{array}{c}\text { Other national and } \\
\text { provincial protective } \\
\text { species }\end{array}$ & Generally important \\
& None & Unimportant \\
\hline
\end{tabular}

The assessment of importance of biodiversity conservation is focus on the assessment of importance of ecosystems and species conservation. The study assessed the regional biodiversity conservation importance by the total number of species in ecosystems or species ratios and important conservation species distribution.

The assessment was divided into 4 levels including unimportant, generally important, important and extremely important by GIS.

\subsection{Sources of data and preprocessing}

Rainfall, air temperature and solar radiation data was achieved from the China Meteorological data share service network (http://CDC.CMA.gov.CN/). Vegetation and soils data was achieved from the environment and ecological science of Western China data center (http://westdc.westgis.AC.CN/). DEM, NDVI data was achieved from the Institute of geo-spatial data cloud (http://www.gscloud.CN/). LUCC and nature reserve data was achieved from Earth system science data sharing platform (www.geodata.CN). The above data was collected by the end of 2014.

\section{Results}

\subsection{Assessment results of importance of water conservation function}

According to the assessment results of water conservation function, Henan province was divided into 4 areas including extremely important areas, important areas, generally important areas and unimportant areas. The extremely important areas were mainly distributed in Funiu mountain and northern slope of Tongbai mountain and Dabie mountain source of Huai river. The important areas were mainly distributed in Hebi and Jiaozuo and Jiyuan. The generally important areas were mainly distributed in the east of Henan province. Other areas were unimportant areas.

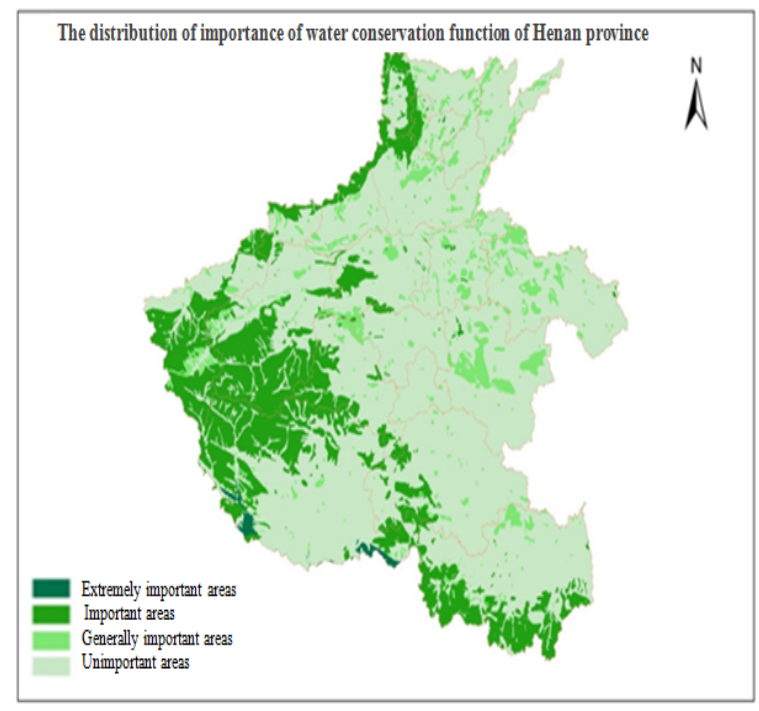

Fig.1 The distribution of importance of water conservation function of Henan province 


\subsection{Assessment results of importance of soil and water conservation function}

According to the assessment results of soil and water conservation function, Henan province was divided into 4 areas including extremely important areas, important areas, generally important areas and unimportant areas. The extremely important areas were mainly distributed in the edge of Taihang mountain and Dabie mountain. The important areas were mainly distributed in the low mountains and hills of Funiu mountain and Dabie mountain. The generally important areas were mainly distributed in the west of Henan province. Other areas were unimportant areas.

\subsection{Assessment results of importance of biodiversity conservation function}

According to the assessment results of biodiversity conservation function, Henan province was divided into 4 areas including extremely important areas, important areas, generally important areas and unimportant areas. The extremely important areas were mainly distributed in Jigong mountain national nature reserve, Neixiang baotianman national nature reserve, Funiu mountain national nature reserve, Taihang mountain smacaca mulatta national nature reserve and Dabie mountain and Tongbai mountain in Xinyang. The important areas were mainly distributed in the provincial nature reserves in Funiu mountain, Dabie mountain and Tongbai mountain. The generally important areas were mainly distributed in the low mountain and hilly areas surrounding by the national and provincial protected areas. Other areas were unimportant areas.

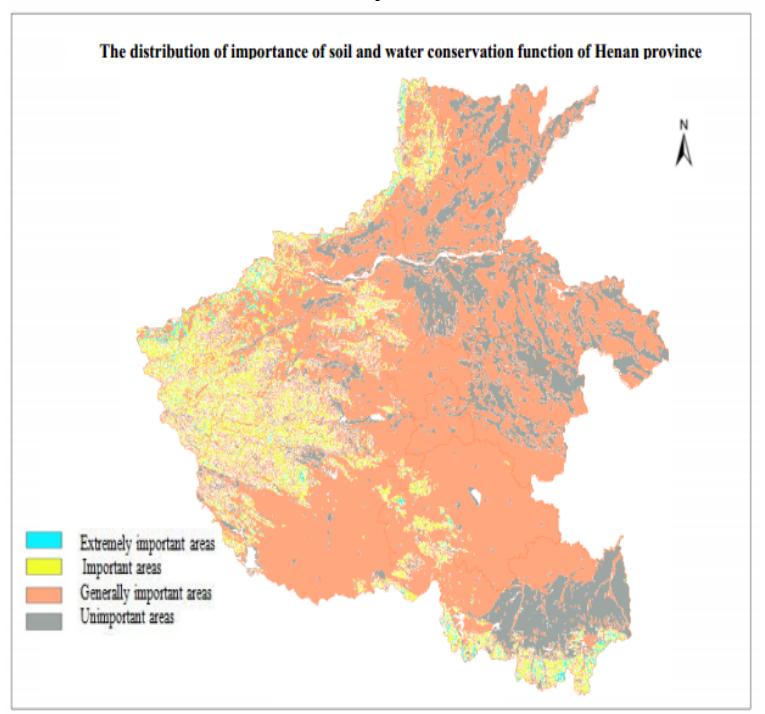

Fig.2 The distribution of importance of soil and water conservation function of Henan province

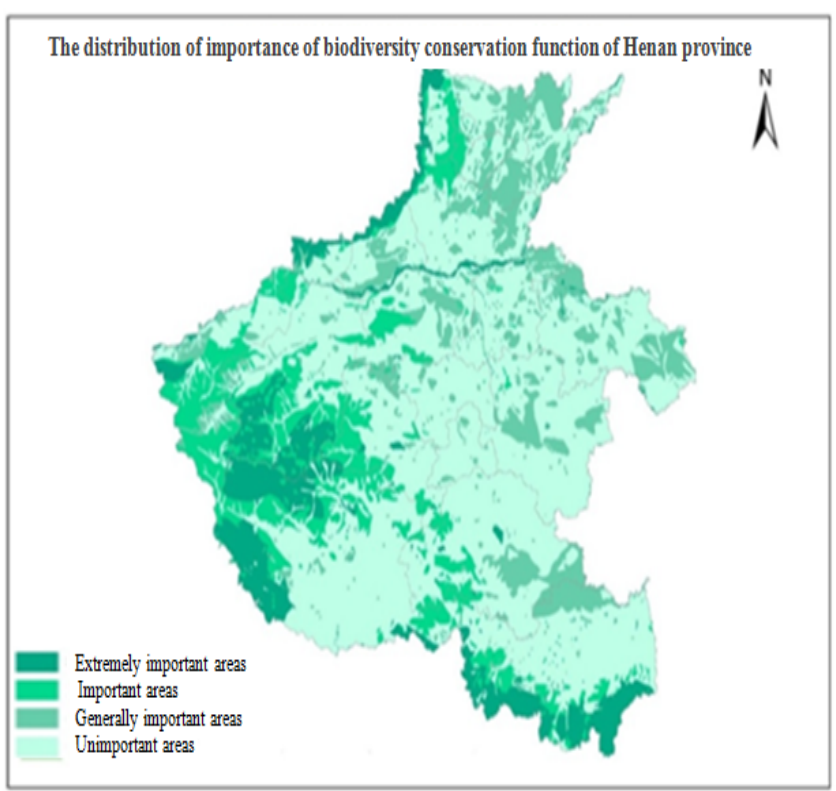

Fig.3 The distribution of importance of biodiversity conservation function of Henan province 


\section{Conclusions}

According to the assessment results of importance of water conservation function, the assessment results of importance of soil and water conservation function and the assessment results of importance of biodiversity conservation function of Henan province, we can conclude that, the extremely important and important area of ecosystem services in Henan province is mainly located in Taihang mountain, Funiu mountain, and Dabie mountain.

\section{References}

Costanza R,d'Arge R, GrootR, et al. The value of the world's ecosystem services and natural capital [J] . Nature, 1997, 387( 6630): 253-260.

Daily G C. Nature's services: societal dependence on natural ecosystems [M] . Island Press: Washington, DC, USA, 1997: 3-6.

MA(Millennium Ecosystem Assessment). Ecosystems and Human Well-Being [M]. Island Press: Washington, DC, USA, 2005: 60-69.

Alexander A M, List J A, Margolis M, et al. A method for valuing global ecosystem services [J] . Ecological Economics, 1998, 27(2): 161-170.

Fu Q, Li B, Yang L, et al. Ecosystem services evaluation and its spatial characteristics in Central Asia's arid regions: A case study in Altay Prefecture, China [J] . Sustainability, 2015, 7(7): 8335-8353.

Xiang B, Ren H L,Ma G W. et al. Assessment of Ecosystem Service Importance in Cheng-Yu Economic Zone [J] . Research of Environmental Sciences,2011,7(24):722-730.

Niu S W, Li Y H, Ma L B. et al. Evaluate the Importance of Ecosystem in Major Function Zoning of Gansu Province [J] . China Population Resources and Environment, 2009,3(19):119-124.

DAILY G. Nature services: societal dependence on natural ecosystem $[\mathrm{M}]$. Washington DC:Island Press, 1997.

The Conceptual Framework Working Group of the Millennium Ecosystem Assessment. Ecosystems and human well-being: a framework for assessment [M ] Millennium ecosystem assessment series. Washington DC: Island Press, 2003.

KING R T. Wildlife and man [J] . N Y Conservationist, 1966, 20(6) :8-11.

HELLIWELL D R. Valuation of wildlife resources [J] . Regional Studies, 1969, 3:4149.

HOLDREN J P , EHRLICH P R . Human population and the global environment [J] . American Scientist, 1974, 62: 282-292.

MARSH G P. Man and nature [M] . New York: Charles Scribner, 1864.

LEOPOLD A. A sandy county almanac and sketches from here and there $[\mathbf{M}]$. New York:Cambridge University Press, 1949.

COSTANZA R, d'ARGE R, de GROAT R, et al. The value of the world's ecosystem services and natural capital [J] . Nat, 1997, 387:253-260.

DAILY G. Nature services: societal dependence on natural ecosystem $[\mathrm{M}]$. Washington DC: Island Press, 1997.

ALEXANDER A M, LIST J A, MARGOLIS A, et al. A method for valuing global ecosystem services [J ] . Ecological Economics, 1998, 27(2):161-170.

Daily G C , eds.Nature' s Services:Societal Dependence on Natural Ecosystems[ M] . Washington DC : Island Press, 1997. 